\title{
Determination of economic threshold level for the timely management of cotton jassid Amrasca bigutulla (Ishida) on okra vegetable crop
}

\author{
Sandeep Kaur', Amandeep Kaur, Gurpreet Kaur and A.K. Dhawan \\ ${ }^{1}$ Department of Vegetable Sciene, Punjab Agriculture University, Ludhiana (Punjab), INDIA \\ Department of Entomology, Punjab Agriculture University, Ludhiana (Punjab), INDIA \\ Corresponding author. Email: amankaur17@pau.edu. \\ Received: September 11, 2016; Revised received: April 6, 2017; Accepted: July 14, 2017
}

\begin{abstract}
A field study was carried out at Vegetable Research Farm PAU, Ludhiana to determine the economic threshold level for the timely management of cotton jassid Amrasca bigutulla (Ishida) on okra vegetable crop. It was observed that significantly lowest jassid nymphal count per leaf in the pooled data ( 0.96 nymphs/leaf) were registered in the treatment where spray against jassid were given at 2 nymphs/leaf stage and first injury grade that is curling and yellowing of leaf margin as compared to others spray stages (1.54-1.72 nymphs/leaf) and unsprayed control (1.75 nymphs/leaf) significantly lowest jassid injury grade was also observed when spray stared at 2 nymphs/ leaf $(0.58)$ and second spray stage curling and yellowing of leaf margin ( 0.65 nymphs/leaf) as against other spray stages (1.13 - 1.60 nymphs/leaf) and unsprayed control (1.63 nymphs/leaf). Maximum plant $(110.33-110.44 \mathrm{~cm})$ was also recorded as against other treatment $(90.80-108.46 \mathrm{~cm})$ and control $(90.13 \mathrm{~cm})$. Total highest fruit yield (120.40-120.75) quintal /ha was also registered in these two treatments. Economic threshold level estimated for the management of cotton jassid on okra crop will help to develop an ecologically safe pest management practices against this pest.
\end{abstract}

Keywords: Amrasca bigutulla, Economic threshold level, Confidor, Okra

\section{INTRODUCTION}

Okra, Abelmoschus esculentus L. is an important summer vegetable crop grown for its tender fruit. It is grown over an area 3.20 thousand hectare in Punjab with annual production 33.35 thousand tons, respectively (Anonymous, 2015). Okra crop is attacked by a number of pest cotton jassid, whitefly, red spider mite, spotted bollworm, Helicoverpa armigera etc. But cotton jassid is the key pest of this crop and causes crop losses of 79.03 per cent (Mahal et al., 1994). Being vegetable crop, insecticides residue and quantum of insecticides being used on crop is of great concern. Farmers are using sprays indiscriminately against this pest. Little work has been done on the estimation of ETH level for timely application of insecticide for the control of this pest (Wagon and Wagon 2015). So, the present study in which different economic threshold levels were evaluated for the management of cotton jassid on okra crop will help to develop an ecologically safe pest management practices against this pest.

\section{MATERIALS AND METHODS}

Okra Abelmoschus esculentus L. variety Punjab Padmini was sown in the first week of July. The trial was laid out in randomized block design and replicated thrice. The plot size was kept $10 \mathrm{~m}^{2}$ with row to row and plant to plant spacing of $45 \times 30 \mathrm{~cm}$. Eight treat- ments i.e. economic levels for the control of cotton jassid were given as per Table 1. Sprays were given on the attainment of respective ETH level in the respective treatment. All the treatments were compared with untreated control. The spray of imidacloprid (confidor $17.8 \mathrm{SL}) @ 40 \mathrm{ml} /$ acre was given in the treatment only on attainment of respective eth level. The jassid nymphs from three leaves (top, middle and bottom) from randomly selected 5 plants in each plot twice a week were recorded. ETH level 2nymphs/leaf was attained after 15 days after germination and sprays as imidacloprid 17.8 SL @ 40ml/ha was given. In the same treatment, second time this level of 2 nymphs/leaf was obtained at 60 days after germination and the second spray was given on the same day. The ETH level of 5 nymph/ leaf was obtained only on 60 days after germination and single spray of imidacloprid was given. The rest of ETH level 7, 10 and 15 nymphs/leaf were never obtained during crop season may be due to heavy to intermittent rain conditions between $21-45$ days after germination. In case of damage symptom based ETH level, the ETH level: spray on curling and yellowing of leaf margin stage was first observed on 15 days after germination and spray was given at this stage. Second time, this stage was observed 60 days after germination and second spray was given then. The other ETH level: spray on curling and yellowing of $50 \%$ leaf lamina was first notice only in 60 days 
Table 1. Sprays given in different treatments on the attainment of respective ETH level of Jassid in okra crop.

\begin{tabular}{|c|c|c|c|c|}
\hline S. $\mathbf{N}$. & Treatments & \multicolumn{2}{|c|}{ Dates of sprays given in different treatments } & Total sprays \\
\hline T1 & 2 nymphs/leaf & $1^{\text {st }}$ Spray & $2^{\text {nd }}$ Spray & 2 \\
\hline $\mathrm{T} 2$ & 5 nymphs/leaf & 15 DAG & $60 \mathrm{DAG}$ & 1 \\
\hline $\mathrm{T} 3$ & 7 nymphs/leaf & - & $60 \mathrm{DAG}$ & - \\
\hline $\mathrm{T} 4$ & 10 nymphs/leaf & - & - & - \\
\hline $\mathrm{T} 5$ & 15 nymphs/leaf & - & - & - \\
\hline T6 & $\begin{array}{l}\text { It }^{\text {st }} \text { injury grade (Curling and yellow- } \\
\text { ing of leaf margins) }\end{array}$ & $15 \mathrm{DAG}$ & $60 \mathrm{DAG}$ & 2 \\
\hline $\mathrm{T} 7$ & $\begin{array}{l}2^{\text {rd }} \text { injury grade (Curling and yellowing } \\
\text { of } 50 \% \text { leaf lamina) }\end{array}$ & - & $60 \mathrm{DAG}$ & 1 \\
\hline $\mathrm{T} 8$ & $\begin{array}{l}3^{\text {rd }} \text { injury grade (Curling and yellow- } \\
\text { ing of } 100 \% \text { leaf lamina) }\end{array}$ & - & - & - \\
\hline T9 & Untreated control & - & - & - \\
\hline
\end{tabular}

Table 2. Incidence of jassid nymphs in different ETH levels in okra crop.

\begin{tabular}{|c|c|c|c|c|c|c|c|c|c|c|c|c|}
\hline \multirow[t]{2}{*}{ S.N. } & \multirow[t]{2}{*}{ Treatments } & \multicolumn{11}{|c|}{ Jassid nymphs/leaf Days after germination (DAG)* } \\
\hline & & 14 & 21 & 28 & 35 & 42 & 49 & 56 & 63 & 70 & 77 & $\begin{array}{l}\text { Poole } \\
\text { d } \\
\text { mean }\end{array}$ \\
\hline $\mathrm{T}_{1}$ & 2nymphs/leaf & $\begin{array}{l}0.7 \\
3\end{array}$ & $\begin{array}{l}1.6 \\
7\end{array}$ & $\begin{array}{l}0.46^{\mathrm{a}} \\
(1.21)\end{array}$ & $\begin{array}{l}0.88^{\mathrm{a}} \\
(1.37)\end{array}$ & $\begin{array}{l}0.73^{\mathrm{a}} \\
(1.31)\end{array}$ & $\begin{array}{l}1.10^{\mathrm{a}} \\
(1.44)\end{array}$ & $\begin{array}{l}0.7 \\
5\end{array}$ & $\begin{array}{l}1.48^{\mathrm{a}} \\
(1.57)\end{array}$ & $\begin{array}{l}0.55^{\mathrm{a}} \\
(1.24)\end{array}$ & $\begin{array}{l}1.27^{\mathrm{a}} \\
(1.50)\end{array}$ & $\begin{array}{l}0.96^{\mathrm{a}} \\
(1.39)\end{array}$ \\
\hline $\mathrm{T}_{2}$ & 5 nymphs/leaf & $\begin{array}{l}0.7 \\
6\end{array}$ & $\begin{array}{l}1.5 \\
6\end{array}$ & $\begin{array}{l}2.46^{\mathrm{b}} \\
(1.84)\end{array}$ & $\begin{array}{l}136^{\mathrm{b}} \\
(1.53)\end{array}$ & $\begin{array}{l}1.94^{\mathrm{b}} \\
(1.71)\end{array}$ & $\begin{array}{l}2.00^{b} \\
(1.73)\end{array}$ & $\begin{array}{l}1.0 \\
0\end{array}$ & $\begin{array}{l}2.28^{\mathrm{a}} \\
(1.80)\end{array}$ & $\begin{array}{l}0.68^{\mathrm{a}} \\
(1.29)\end{array}$ & $\begin{array}{l}1.36^{\mathrm{b}} \\
(1.53)\end{array}$ & $\begin{array}{l}1.54^{b} \\
(1.58)\end{array}$ \\
\hline $\mathrm{T}_{3}$ & 7 nymphs/leaf & $\begin{array}{l}0.5 \\
9\end{array}$ & $\begin{array}{l}1.7 \\
2\end{array}$ & $\begin{array}{l}2.64^{\mathrm{b}} \\
(1.90)\end{array}$ & $\begin{array}{l}1.66^{b} \\
(1.62)\end{array}$ & $\begin{array}{l}1.82^{\mathrm{b}} \\
(1.67)\end{array}$ & $\begin{array}{l}1.94^{b} \\
(1.71)\end{array}$ & $\begin{array}{l}1.1 \\
1\end{array}$ & $\begin{array}{c}\mathbf{1 . 7 9}^{\mathrm{b}} \\
(1.67)\end{array}$ & $\begin{array}{l}1.70^{\mathrm{b}} \\
(1.64)\end{array}$ & $\begin{array}{l}1.60^{\mathrm{a}} \\
(1.61)\end{array}$ & $\begin{array}{l}1.65^{b c} \\
(1.62)\end{array}$ \\
\hline $\mathrm{T}_{4}$ & $\begin{array}{l}10 \text { nymphs/ } \\
\text { leaf }\end{array}$ & $\begin{array}{l}0.8 \\
4\end{array}$ & $\begin{array}{l}1.4 \\
4\end{array}$ & $\begin{array}{l}1.92^{\mathrm{b}} \\
(1.70)\end{array}$ & $\begin{array}{l}1.73^{b} \\
(1.64)\end{array}$ & $\begin{array}{l}2.49^{b} \\
(1.86)\end{array}$ & $\begin{array}{l}2.31^{b} \\
(1.81)\end{array}$ & $\begin{array}{l}1.2 \\
0\end{array}$ & $\begin{array}{l}2.20^{\mathrm{a}} \\
(1.78)\end{array}$ & $\begin{array}{l}1.87^{b} \\
(1.69)\end{array}$ & $\begin{array}{l}1.71^{\mathrm{b}} \\
(1.64)\end{array}$ & $\begin{array}{l}1.77^{\mathrm{bcd}} \\
(1.65)\end{array}$ \\
\hline $\mathrm{T}_{5}$ & $\begin{array}{l}15 \text { nymphs/ } \\
\text { leaf }\end{array}$ & $\begin{array}{l}0.7 \\
0\end{array}$ & $\begin{array}{l}1.3 \\
5\end{array}$ & $\begin{array}{l}1.92^{b} \\
(1.70)\end{array}$ & $\begin{array}{l}1.84^{\mathrm{b}} \\
(1.67)\end{array}$ & $\begin{array}{l}3.78^{\mathrm{c}} \\
(2.18)\end{array}$ & $\begin{array}{l}2.62^{b} \\
(1.89)\end{array}$ & $\begin{array}{l}1.1 \\
5\end{array}$ & $\begin{array}{l}3.75^{\mathrm{b}} \\
(2.16)\end{array}$ & $\begin{array}{l}1.93^{\mathrm{b}} \\
(1.71)\end{array}$ & $\begin{array}{l}1.53 \\
(1.59)\end{array}$ & $\begin{array}{l}2.06^{\text {de }} \\
(1.72)\end{array}$ \\
\hline $\mathrm{T}_{6}$ & $\begin{array}{l}\mathrm{I}^{\text {st }} \text { injury } \\
\text { grade } \\
\text { (Curling and } \\
\text { yellowing of } \\
\text { leaf margins) }\end{array}$ & $\begin{array}{l}0.7 \\
0\end{array}$ & $\begin{array}{l}1.0 \\
6\end{array}$ & $\begin{array}{l}0.42^{\mathrm{a}} \\
(1.19)\end{array}$ & $\begin{array}{l}0.64^{\mathrm{a}} \\
(1.28)\end{array}$ & $\begin{array}{l}1.44^{\mathrm{a}} \\
(1.54)\end{array}$ & $\begin{array}{l}1.38^{\mathrm{a}} \\
(1.52)\end{array}$ & $\begin{array}{l}0.9 \\
1\end{array}$ & $\begin{array}{l}1.75^{\mathrm{a}} \\
(1.64)\end{array}$ & $\begin{array}{l}0.39^{\mathrm{a}} \\
(1.18)\end{array}$ & $\begin{array}{l}1.15^{\mathrm{a}} \\
(1.46)\end{array}$ & $\begin{array}{l}0.98^{\mathrm{a}} \\
(1.39)\end{array}$ \\
\hline $\mathrm{T}_{7}$ & $\begin{array}{l}2^{\text {rd }} \text { injury } \\
\text { grade (Curling } \\
\text { and yellowing } \\
\text { of } 50 \% \text { leaf } \\
\text { lamina) }\end{array}$ & $\begin{array}{l}0.5 \\
7\end{array}$ & $\begin{array}{l}1.8 \\
0\end{array}$ & $\begin{array}{l}2.75^{\mathrm{b}} \\
(1.92)\end{array}$ & $\begin{array}{l}1.60^{\mathrm{b}} \\
(1.60)\end{array}$ & $\begin{array}{l}3.02^{\mathrm{c}} \\
(1.99)\end{array}$ & $\begin{array}{l}2.00^{\mathrm{b}} \\
(1.72)\end{array}$ & $\begin{array}{l}1.8 \\
6\end{array}$ & $\begin{array}{l}3.88^{\mathrm{b}} \\
(2.19)\end{array}$ & $\begin{array}{l}0.80^{\mathrm{a}} \\
(1.32)\end{array}$ & $\begin{array}{l}1.18^{\mathrm{a}} \\
(1.47)\end{array}$ & $\begin{array}{l}1.94 \\
\text { cde } \\
(1.68)\end{array}$ \\
\hline $\mathrm{T}_{8}$ & $\begin{array}{l}3^{\text {rd }} \text { injury } \\
\text { grade (Curling } \\
\text { and yellowing } \\
\text { of } 100 \% \text { leaf } \\
\text { lamina) }\end{array}$ & $\begin{array}{l}0.5 \\
0\end{array}$ & $\begin{array}{l}1.7 \\
3\end{array}$ & $\begin{array}{l}2.37^{\mathrm{b}} \\
(1.79)\end{array}$ & $\begin{array}{l}2.15^{\mathrm{c}} \\
(1.77)\end{array}$ & $\begin{array}{l}2.35^{\mathrm{b}} \\
(1.81)\end{array}$ & $\begin{array}{l}2.46^{\mathrm{b}} \\
(1.85)\end{array}$ & $\begin{array}{l}0.9 \\
8\end{array}$ & $\begin{array}{l}3.35^{\mathrm{b}} \\
(2.08)\end{array}$ & $\begin{array}{l}1.72^{\mathrm{b}} \\
(1.64)\end{array}$ & $\begin{array}{l}1.75^{\mathrm{a}} \\
(1.65)\end{array}$ & $\begin{array}{l}1.93 \\
\text { cde } \\
(1.69)\end{array}$ \\
\hline $\mathrm{T}_{9}$ & $\begin{array}{l}\text { Untreated } \\
\text { control }\end{array}$ & $\begin{array}{l}0.8 \\
9\end{array}$ & $\begin{array}{l}2.3 \\
1\end{array}$ & $\begin{array}{l}2.38^{\mathrm{b}} \\
(1.79)\end{array}$ & $\begin{array}{l}2.33^{c} \\
(1.82)\end{array}$ & $\begin{array}{l}3.47^{\mathrm{c}} \\
(2.10)\end{array}$ & $\begin{array}{l}2.71^{\mathrm{b}} \\
(1.91)\end{array}$ & $\begin{array}{l}1.0 \\
0\end{array}$ & $\begin{array}{l}2.64^{\mathrm{a}} \\
(1.89)\end{array}$ & $\begin{array}{l}1.86^{b} \\
(1.69)\end{array}$ & $\begin{array}{l}1.87^{\mathrm{a}} \\
(1.69)\end{array}$ & $\begin{array}{l}2.14^{\mathrm{e}} \\
(1.75)\end{array}$ \\
\hline $\begin{array}{l}\mathrm{CD}(\mathrm{p} \\
= \\
0.05)\end{array}$ & - & NS & NS & $(0.48)$ & $(0.21)$ & $(0.30)$ & $(0.27)$ & NS & $(0.38)$ & $(0.19)$ & $(0.08)$ & $(0.08)$ \\
\hline $\begin{array}{l}\text { C.V. } \\
(\%)\end{array}$ & & $\begin{array}{l}6.5 \\
9\end{array}$ & $\begin{array}{l}10 . \\
97\end{array}$ & 16.66 & 7.89 & 9.82 & 9.01 & $\begin{array}{l}7.9 \\
7\end{array}$ & 11.99 & 7.60 & 2.99 & 10.14 \\
\hline
\end{tabular}

Figures in parentheses are $\sqrt{ } n+1$ transformed value. 
fter germination and single spray was given. The next ETH level: spray in curling and yellowing of $100 \%$ leaf lamina was never obtained. The methodology given for injury grade was given by Mahal et. al (1994). Observations on other parameters like plant height and fruit yield were also recorded plot wise which later converted to quintal/hectare.

\section{RESULTS AND DISCUSSION}

Population incidence of jassid in different ETH level: As presented in Table 2 the difference in jassid nymphal counts was non significant (0.50-0.89 and 1.062.31 nymphs on 14 and $21 \mathrm{DAG}$, resp.). On $28^{\text {th }}$ days after germination, significantly low nymphal counts (0.42-0.46 nymphs/leaf) were recorded in ETH level; 2nymph/leaf and other ETH level: spray on curling and yellowing of leaf margins against other ETH levels (1.92-2.75 nymphs/leaf) and control (2.38 nymphs/ leaf). Similarly, on 35, 42, 49 DAG, consistently low nymphal counts were registered in the former two treatments. On $56^{\text {th }}$ DAG, the difference among all ETH levels becomes non significant (0.75-1.86 nymphs/leaf). On $63^{\text {rd }}$ DAG, again consistently lowest jassid counts were registered in treatments $(1.48-2.28$ nymphs/leaf) as against other treatments (1.79-3.88 nymphs/leaf) and control (2.64 nymphs/leaf). On $70^{\text {th }}$ DAG, same trend was observed. However, population in ETH level: spray on curling and yellowing of $50 \%$ leaf lamina was also registered significantly lowest (0.80 nymphs/leaf). On $77^{\text {th }}$ DAG, significantly lowest jassid nymphal counts (1.15-1.27 nymphs/leaf) were recorded in 2 nymphs ETH: / leaf ; spray on curling and yellowing of leaf margins, curling and yellowing of $50 \%$ leaf lamina followed by ETH level: 5 nymphs/ leaf (1.36 nymphs/leaf) as against other treatments (1.53-1.75 nymphs/leaf) and control (1.87 nymphs/ leaf). In the pooled data, at $5 \%$ level of significance, lowest nymphal counts per leaf were registered (0.960.98 nymphs/leaf) in ETH level: 2nymphs/leaf, spray on curling and yellowing of leaf margins followed by ETH level: 5nymphs/leaf (1.54 nymphs/leaf) as against other ETH level (1.65-2.06 nymphs/leaf) and control (2.14 nymphs/leaf). The present study showed that imidacloprid caused significant reduction in cotton jassid on okra when sprayed at right time. The present finding are also in tune with the work of Babu and Santharam (2002) who reported that imidacloprid gave significantly superior control to standard checks: dimethoate and methyl-o-demeton. Preethan et al., (2008) also reported that imidacloprid 17.8 SL had longer persistence and was superior to the conventional insecticides methyl demeton in controlling cotton jassid crop.

Jassid injury grade: Significantly lowest jassid injury grade was observed in ETH levels: 2nymphs/leaf; curling and yellowing of leaf margins (0.58-0.65 nymphs/ leaf) as compared to other ETH levels (1.13-1.63 nymphs/leaf) and control (1.77 nymphs/leaf) (Table 3). Present finding are also supported by the work of Mahal et al., (1994) who reported that injury grade II gave the maximum monetary benefit against unit cost of protection measures. Leaves of okra showing yellowing and cupping at margins in at least 50 per cent of the plants, injury grade II and fully protected crop were on a par and yielded higher than that in case of injury grade III and unsprayed crop. Wagan and Wagan (2015) also observed that with increase in days of germination and infestation the crop till harvest jassid population were significantly increase with increase of plant vegetative growth. Spray should be done only at the time of appearance of $3^{\text {rd }}$ grade injury symptoms of yellowing and curling along the margin of the leaves in the middle to upper portion of the crop canopy of atleaset $25 \%$ plants in the cotton file (Vennilla et al 2007).

Plant height: Significantly higher plant height (110.30 $-110.4 \mathrm{~cm}$ ) was recorded in ETH levels : 2nymphs/ leaf; curling and yellowing of leaf margins followed by ETH levels: 5 nymphs/leaf; curling and yellowing of $50 \%$ leaf lamina $(106.83-108.46 \mathrm{~cm})$ as compared to other ETH levels (90.80-98.20 cm) and control (90.13 cm) (Table 4). Mahal et al. (1994) also supported our findings and reported that jassid population had an inverse relationship with plant height and seed yield. Rahman (2014) also corroborate our findings and reported that there is positive correlation between plant height and yield whereas negatively correlate with jassid population.

Total yield: Significantly highest total yield 120.75 q/ ha were registered in ETH levels: 2nymphs/leaf; curling and yellowing of leaf margins followed by ETH levels: 5 nymphs/leaf $(112.44 \mathrm{q} / \mathrm{ha})$ and other ETH levels (65.02-91.46q/ha) and control (63.70q/ha) (Table 4).

Economics: Treatment 1 and treatment 6 performed as the best treatment in terms of benefit cost ratio (57.20 and 57.15) followed by treatment 2. On the other hand, the lowest B:C ratio was found in treatment $3(0.35)$. The highest gross income was also reported from treatment $1($ Rs. 68,460) and treatment 6 (Rs. 68,040) with maximum net income (Table 5). On the other hand lowest gross income and net income was recorded from treatment 3 ( 7 nymphs/leaf).

\section{Conclusion}

In case of ETH level: 2numphs/ leaf 2 sprays of imidacloprid were given (15 and $60 \mathrm{DAG}$ ) which resulted in significantly better control of pest at right time. Then, another ETH level: 5 nymphs / leaf, where single spray of imidacloprid at late stage of the crop i.e 60 DAG could protect the crop. So it could contribute a little to the control of pest, but found superior to other treatments where respective ETH level had never been obtained due to comparatively low incidence of pest 
Table 3. Jassid injury grade in different ETH levels in okra.

\begin{tabular}{|c|c|c|c|c|c|c|c|c|c|c|c|c|}
\hline & \multirow[t]{2}{*}{ Treatments } & \multicolumn{10}{|c|}{ Jassid injury grade days after germination (DAG) } & \multirow[b]{2}{*}{ Mean } \\
\hline & & $\overline{14}$ & $21 *$ & $28 *$ & $35 *$ & $42 *$ & 49 & 56 & 63 & 70 & 77 & \\
\hline $\mathrm{T} 1$ & 2nymphs/leaf & 0.01 & 1.05 & 0.03 & 0.12 & 0.10 & 0.34 & 0.95 & 1.56 & 0.57 & 1.03 & 0.58 \\
\hline $\mathrm{T} 2$ & 5 nymphs/leaf & 0.22 & 1.00 & 0.95 & 0.94 & 0.85 & 1.01 & 1.65 & 2.50 & 1.08 & 1.06 & 1.13 \\
\hline T3 & 7 nymphs/leaf & 0.29 & 0.98 & 1.05 & 1.12 & 0.73 & 0.94 & 1.60 & 2.35 & 2.56 & 2.15 & 1.38 \\
\hline $\mathrm{T} 4$ & 10 nymphs/leaf & 0.20 & 1.13 & 1.00 & 1.30 & 1.13 & 1.23 & 1.52 & 2.45 & 1.89 & 1.98 & 1.39 \\
\hline T5 & 15 nymphs/leaf & 0.23 & 1.15 & 0.98 & 1.42 & 2.06 & 1.51 & 2.01 & 2.85 & 1.87 & 1.92 & 1.60 \\
\hline T6 & $\begin{array}{l}\text { I }^{\text {st }} \text { injury grade } \\
\text { (Curling and yellow- } \\
\text { ing of leaf margins) }\end{array}$ & 0.03 & 0.91 & 0.02 & 0.14 & 0.20 & 0.45 & 0.85 & 1.80 & 0.82 & 1.04 & 0.65 \\
\hline $\mathrm{T} 7$ & $\begin{array}{l}2^{\text {rd }} \text { injury grade } \\
\text { (Curling and yellow- } \\
\text { ing of } 50 \% \text { leaf lam- } \\
\text { ina) }\end{array}$ & 0.35 & 1.16 & 1.12 & 1.34 & 1.80 & 1.03 & 1.76 & 2.91 & 1.47 & 1.60 & 1.46 \\
\hline T8 & $\begin{array}{l}3^{\text {rd }} \text { injury grade } \\
\text { (Curling and yellow- } \\
\text { ing of } 100 \% \text { leaf } \\
\text { lamina) }\end{array}$ & 0.29 & 1.15 & 1.08 & 1.50 & 1.23 & 1.22 & 1.96 & 2.75 & 2.66 & 2.48 & 1.63 \\
\hline T9 & Untreated control & 0.31 & 1.12 & 1.10 & 1.54 & 2.00 & 1.60 & 2.19 & 2.57 & 2.56 & 2.68 & 1.77 \\
\hline
\end{tabular}

* There were heavy to intermittent rains between $21-42$ DAG during crop season

Table 4. Effect of different treatments on plant height and fruit yield of okra.

\begin{tabular}{|c|c|c|c|c|c|c|}
\hline \multirow[t]{2}{*}{ S.N. } & \multirow{2}{*}{ Treatments } & \multicolumn{4}{|c|}{ Plant height (cm) } & \multirow{2}{*}{$\begin{array}{l}\text { Total fruit yield } \\
\text { (q/ha) }\end{array}$} \\
\hline & & 15 DAG & 30DAG & 45 DAG & 60 DAG & \\
\hline $\mathrm{T}_{1}$ & 2 nymphs/leaf & 19.86 & 55.66 & 109.93 & 110.33 & $120.75^{\mathrm{a}}$ \\
\hline $\mathrm{T}_{2}$ & 5 nymphs/leaf & 21.40 & 57.06 & 105.46 & 108.46 & $112.44^{\mathrm{ab}}$ \\
\hline $\mathrm{T}_{3}$ & 7 nymphs/leaf & 20.60 & 50.80 & 91.13 & 95.61 & $65.02^{\mathrm{d}}$ \\
\hline $\mathrm{T}_{4}$ & 10 nymphs/leaf & 19.86 & 46.93 & 92.73 & 98.20 & $77.47^{\mathrm{c}}$ \\
\hline $\mathrm{T}_{5}$ & 15 nymphs/leaf & 21.20 & 48.06 & 86.53 & 90.80 & $75.29^{\mathrm{cd}}$ \\
\hline $\mathrm{T}_{6}$ & $\begin{array}{l}\text { I }^{\text {st }} \text { injury grade (Curling and } \\
\text { yellowing of leaf margins) }\end{array}$ & 22.26 & 55.80 & 102.60 & 110.40 & $120.40^{\mathrm{a}}$ \\
\hline $\mathrm{T}_{7}$ & $\begin{array}{l}2^{\text {rd }} \text { injury grade (Curling and } \\
\text { yellowing of } 50 \% \text { leaf lamina) }\end{array}$ & 21.53 & 46.40 & 104.13 & 106.83 & $91.46^{\mathrm{c}}$ \\
\hline $\mathrm{T}_{8}$ & $\begin{array}{l}3^{\text {rd }} \text { injury grade (Curling and } \\
\text { yellowing of } 100 \% \text { leaf lamina) }\end{array}$ & 20.93 & 48.73 & 85.73 & 92.73 & $70.85^{d}$ \\
\hline $\mathrm{T}_{9}$ & Untreated control & 20.26 & 46.00 & 84.73 & 90.13 & $63.70^{\mathrm{d}}$ \\
\hline $\begin{array}{l}\mathrm{CD}(\mathrm{p} \\
=0.05)\end{array}$ & - & NS & NS & NS & NS & 18.88 \\
\hline $\begin{array}{l}\text { C.V. } \\
(\%)\end{array}$ & - & 9.07 & 13.04 & 12.40 & 11.41 & 12.17 \\
\hline S.N. & Treatments & $\begin{array}{c}\text { Yield in } \\
\text { quintal/ha }\end{array}$ & $\begin{array}{c}\text { Yield over } \\
\text { control }\end{array}$ & $\begin{array}{c}\text { Gross } \\
\text { income }\end{array}$ & $\begin{array}{c}\text { Net } \\
\text { income }\end{array}$ & $\begin{array}{l}\text { Benefit : cost } \\
\text { ratio }\end{array}$ \\
\hline $\mathrm{T}_{1}$ & 2 nymphs/leaf & 120.75 & 57.05 & 68,460 & 67,290 & 57.205 \\
\hline $\mathrm{T}_{2}$ & 5 nymphs/leaf & 112.44 & 48.74 & 58,488 & 57,318 & 48.989 \\
\hline $\mathrm{T}_{3}$ & 7 nymphs/leaf & 65.02 & 1.32 & 1,584 & 414 & 0.353 \\
\hline $\mathrm{T}_{4}$ & 10 nymphs/leaf & 77.47 & 13.77 & 16,524 & 15,354 & 13.123 \\
\hline $\mathrm{T}_{5}$ & 15 nymphs/leaf & 75.29 & 11.59 & 13,908 & 12,738 & 10.887 \\
\hline $\mathrm{T}_{6}$ & $\begin{array}{l}\mathrm{I}^{\text {st }} \text { injury grade (Curling and } \\
\text { yellowing of leaf margins) }\end{array}$ & 120.40 & 56.70 & 68,040 & 66,870 & 57.153 \\
\hline $\mathrm{T}_{7}$ & $\begin{array}{l}2^{\text {rd }} \text { injury grade (Curling and } \\
\text { yellowing of } 50 \% \text { leaf lamina) }\end{array}$ & 91.46 & 27.76 & 33,312 & 32,142 & 27.47 \\
\hline $\mathrm{T}_{8}$ & $\begin{array}{l}3^{\text {rd }} \text { injury grade (Curling and } \\
\text { yellowing of } 100 \% \text { leaf lamina) }\end{array}$ & 70.85 & 7.15 & 8,580 & 7,410 & 6.33 \\
\hline $\mathrm{T}_{9}$ & Untreated control & 63.7 & & & & \\
\hline
\end{tabular}

Rate of okra: $12 / \mathrm{kg}$, Cost of spray: Rs. 432, Daily wage: 123/day 
because of heavy and intermittent rains from $21-45$ DAG and the untreated control. Therefore, it is clear from data in treatments where sprays were given timely, more yield were obtained such as curling and yellowing of leaf margin. The treatment in which spray was given at higher level of pest, like wise yield was also affected i.e. ETH level 5 nymphs/ leaf. However, in treatments where protection with insecticides was given against pest, were found superior to the treatment where no spray was given and untreated control. Lower the jassid population higher the fruit yield. Thus, from the above discussion it is concluded that sprays effective for the control of cotton jassid should be initiated at right ETH level: 2 nymphs/leaf; spray on curling and yellowing of leaf margins. The study revealed that increase in yield/ha of okra with decrease rate of jassid population, height of the plant and fruit yield might be obtained by adoption ETH level of 2 nymphs/ leaf or $2^{\text {nd }}$ injury grade- yellowing and cupping of the leaf margin.

\section{REFERENCES}

Anonymous, (2015). Package of practice for vegetable crops. Punjab Agricultural University, Ludhiana, p-01.

Babu, R.K and Santharam, G. (2002). Bioefficacy of imidacloprid against leaf hopper, Empoasca kerri on groundnut. Annals of Plant Protection 10 (1): 69-71.

Mahal, M. S, Brar, L. S, Singh, R. and Singh, B. (1994). Influence of varying magnitude of jassid injury on seed yield of okra and economics of its control. Journal of Insect Science 7 (2): 129-132

Preethan, G, Manoharan, T, Kuttalam, S and Stanley, J. (2008). Persistent toxicity of imidacloprid against aphid, Aphis gossypii and leaf hopper, Amrasca bigutulla on cotton. Pesticide Research Journal 20(2): 197-200.

Rahman, A. (2014). Development of management practices against jassid (Amrasca devastans) in okra. Msc (Agri.) thesis.Sher-e-Bangla Agricultural University, Dhaka, Bangladesh.

Wagon, T. A. and Wagon, Z.A.015). Natural enemies associate with jassid on okra crop under natural agro ecosystem. Advances in Life Science and Technology. 34: 117-121

Vennilla, S, Biradar, B.K,Sabesh, M. and Bambawala, O. M. (2007). Know your cotton insect pest jassid. Crop Prot Bull. 2:11. 